This work is licensed under a Creative Commons Attribution License (CC BY 4.0).

\title{
Three new species of Eusarcus Perty, 1833 (Opiliones, Gonyleptidae) from Brazilian caves
}

\author{
Gilson Argolo dos SANTOS JÚNIOR ${ }^{1}$, Ludson Neves de ÁZARA ${ }^{2, *}$ \& \\ Rodrigo Lopes FERREIRA ${ }^{3}$ \\ ${ }^{1,3}$ Centro de Estudos em Biologia Subterrânea, Setor de Biodiversidade Subterrânea, \\ Departamento de Ecologia e Conservação, Universidade Federal de Lavras, \\ Campus Universitário, 37200-900, Minas Gerais, Brazil. \\ ${ }^{2}$ Laboratório de Aracnologia, Departamento de Invertebrados, Museu Nacional, Universidade Federal \\ do Rio de Janeiro, Quinta da Boa Vista, São Cristóvão, 20940-040, Rio de Janeiro, Brazil. \\ *Corresponding author: ludsonazara@yahoo.com.br \\ 1Email: gilsonjr_2006@hotmail.com \\ ${ }^{3}$ Email: drops@ufla.br \\ ${ }^{1}$ urn:1sid:zoobank.org:author:DB6382CF-CDB5-4EB1-8E59-C32AA8D8B1FD \\ ${ }^{2}$ urn:lsid:zoobank.org:author:4ECF193A-694C-43CE-8EE6-F197EDDA4414 \\ ${ }^{3}$ urn:lsid:zoobank.org:author:DAADEEBA-4DE9-44B4-8FD0-A9EAF410420A
}

\begin{abstract}
Three new species of Eusarcus Perty, 1833 are described from Brazilian caves, increasing the number of species of the genus to 40, eight of which have occurrences in caves. Eusarcus capixaba sp. nov. is described from Lapa do Sítio Paraíso Cave, municipality of Ecoporanga, state of Espírito Santo. Eusarcus marmoreus sp. nov. is described from Caverna Archimides Panssini Cave, municipality of Vargem Alta, state of Espírito Santo. Finally, Eusarcus xambioa sp. nov. is described from Caverna da Explosão Cave, municipality of Xambioá, state of Tocantins. Notes on the species' habitats and a distribution map are also provided.
\end{abstract}

Keywords. Arachnida, Gonyleptoidea, Neotropics, Brazil, cave-dwellers.

Santos Júnior G.A., Ázara L.N. \& Ferreira R.L. 2021. Three new species of Eusarcus Perty, 1833 (Opiliones, Gonyleptidae) from Brazilian caves. European Journal of Taxonomy 740: 36-54.

https://doi.org/10.5852/ejt.2021.740.1279

\section{Introduction}

Eusarcus Perty, 1833 is a monophyletic genus that currently comprises 37 species (Hara \& Pinto-daRocha 2010; Saraiva \& DaSilva 2016). The genus was revised by Hara \& Pinto-da-Rocha (2010), who proposed the following unambiguous exclusive synapomorphies in support of its monophyly: unpaired armature present on scutal area III and the distalmost pair of (distal) setae of ventral plate of penis strongly curved. 
The genus has a considerable distributional range, occurring from northeastern to southeastern Brazil, beyond to eastern Uruguay, Paraguay and northeastern Argentina. Species of this genus are usually restricted to forest fragments or habitats with similar conditions, such as riparian forests and caves (Hara \& Pinto-da-Rocha 2010). There are only five described species known to be associated with subterranean environments (all from Brazil): E. aduncus (Mello-Leitão, 1942), E. cavernicola Hara \& Pinto-da-Rocha, 2010, E. elinae Kury, 2008, E. hastatus Sørensen, 1884 and E. sulcatus (Piza, 1940) (Hara \& Pinto-da-Rocha 2010).

Ázara \& Ferreira (2018) recently published a checklist of harvestmen species of the superfamily Gonyleptoidea associated with Brazilian caves, including undescribed species of Eusarcus. Based on that material, the present work aims to describe three new species of Eusarcus associated with Brazilian caves from the states of Espírito Santo and Tocantins, as well as provide ecological notes on their habitats.

\section{Material and methods}

The material examined here is deposited in the Coleção de Invertebrados Subterrâneos de Lavras, Universidade Federal de Lavras (ISLA), Lavras, Minas Gerais State, Brazil. Some types designated here as destroyed were lost in the fire of September $2^{\text {nd }}, 2018$, along with the bulk of the arachnological collection of the National Museum of Rio de Janeiro (MNRJ) (Kury et al. 2018). There is no formal impediment per ICZN rules to describing a species whose holotype was lost before the publication of the description (see Krell \& Marshall 2017 for a discussion on this topic). The species descriptions made here do not repeat the generic characteristics described in Hara \& Pinto-da-Rocha (2010).

All measurements are in millimetres, were taken under a stereo microscope and refer to maximum length and width. Setiferous tubercles $(\mathrm{i}=$ small, $\mathrm{I}=$ large $)$ on pedipalps are given in proximal to distal order. Descriptions and names of colours use the standard names and numbers of the 267 Color Centroids of the NBS/IBCC Color System (http://people.csail.mit.edu/jaffer/Color/Dictionaries\#nbs-iscC) as described in Kury \& Orrico (2006).

Topological nomenclature and integumentary ornamentation follow DaSilva \& Gnaspini (2010). The description pattern and terminology for chaetotaxy of the penis ventral plate follows Kury \& Villarreal (2015); terminology of dorsal scutum types follows Kury \& Medrano (2016); and microsetae names and types follow Kury (2016). Scanning electron microscopy was carried out with a JEOL JSM-6390LV at the Center for Scanning Electron Microscopy of Museu Nacional/Federal University of Rio de Janeiro UFRJ, with an accelerating voltage of $10 \mathrm{kV}$ after sputter-coating with gold-palladium.

Line drawings were made using a stereo microscope with a camera lucida and digitalized using the software Inkscape ver. 0.92. Photographs were taken with a Sony Cybershot DSC-V1 camera attached to a stereo microscope. The software package CombineZP by Alan Hadley (see http://www.hadleyweb.pwp.blueyonder.co.uk/CZP/News.htm, accessed 1 November 2018) was used to create composite images with extended depth of field through the combination of several images taken at different focal planes. The resulting images were edited with Adobe Photoshop CS5. The figures were prepared in CorelDraw X7.
Abbreviations
DSW $=$ dorsal scute width
DSL $=$ dorsal scute length
PAM = paramedian apophysis
PDS = prodorsal spine
$\mathrm{RDS}=$ retrodorsal spine 
For the penis:

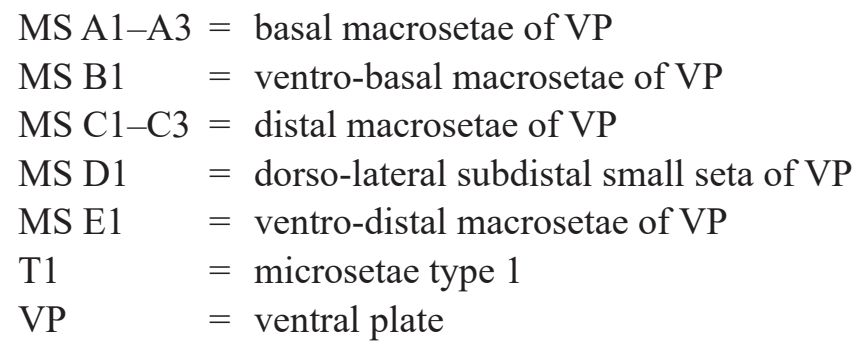

\title{
Results
}

\author{
Class Arachnida Lamarck, 1801 \\ Order Opiliones Sundevall, 1833 \\ Suborder Laniatores Thorell, 1876 \\ Family Gonyleptidae Sundevall, 1833 \\ Subfamily Pachylinae Sørensen, 1884 \\ Genus Eusarcus Perty, 1833 \\ Eusarcus capixaba sp. nov. \\ urn:1sid:zoobank.org:act:E67BD462-5F7E-49D2-AB50-1DE3202F947A
}

Figs $1-3,11$

\section{Diagnosis}

Eusarcus capixaba sp. nov. can be distinguished from all species of the genus by having a pair of high (twice as tall and wide as surrounding granules), round tubercles on scutal area I. Eusarcus capixaba sp. nov. resembles E. aduncus, E. armatus Perty, 1833, E. cavernicola, E. dandara Saraiva \& DaSilva, 2016, E. fulvus Soares \& Soares, 1946, E. mirabilis Pinto-da-Rocha \& Hara, 2010 and E. oxyacanthus Koch, 1839 by the presence of one oblique, proapical, acute and conical apophysis on trochanter IV but can be distinguished by the following characters: low ocularium height, proapical apophysis of coxa IV shorter than trochanter IV length and trochanter IV with dorsally-curved and sinuous promedian apophysis.

\section{Etymology}

The specific epithet 'capixaba' is derived from the Tupi language, meaning 'field land', in allusion to corn and mandioca fields cultivated by local Indian tribes. It also refers to the natives of the Brazilian state of Espírito Santo.

\section{Material examined}

Holotype

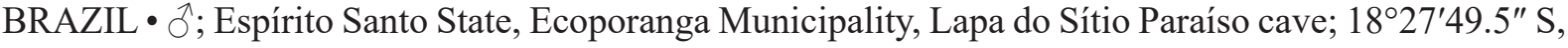
4049'52.2" W; 22 Jul. 2004; R.L. Ferreira et al. leg.; ISLA 12966 (destroyed).

Paratype

BRAZIL $・ 1$ \% ; same collection data as for holotype; ISLA 66189 (destroyed).

\section{Description}

Male (holotype, ISLA 12966)

MeAsurements. DSL 4.32, DSW 3.28, femur I 2.26, II 5.69, III 4.18, IV 5.24. 
Dorsum (Fig. 1A, C). Acuminate PAM; median paracheliceral projection similar in size to PAM. Low ocularium with two low tubercles (half ocularium height). Carapace with scattered granules. Scutal areas I-IV with scattered tubercles; scutal area I with antero-lateral pair of tubercles (higher than the others of the other areas) with black inner pigmentation; scutal area III with median oblique spine that is bifurcate apically and longitudinally. Posterior margin of dorsal scutum with scattered granules. Free tergites I-III with a defined row of granules. Anal operculum with scattered granules.

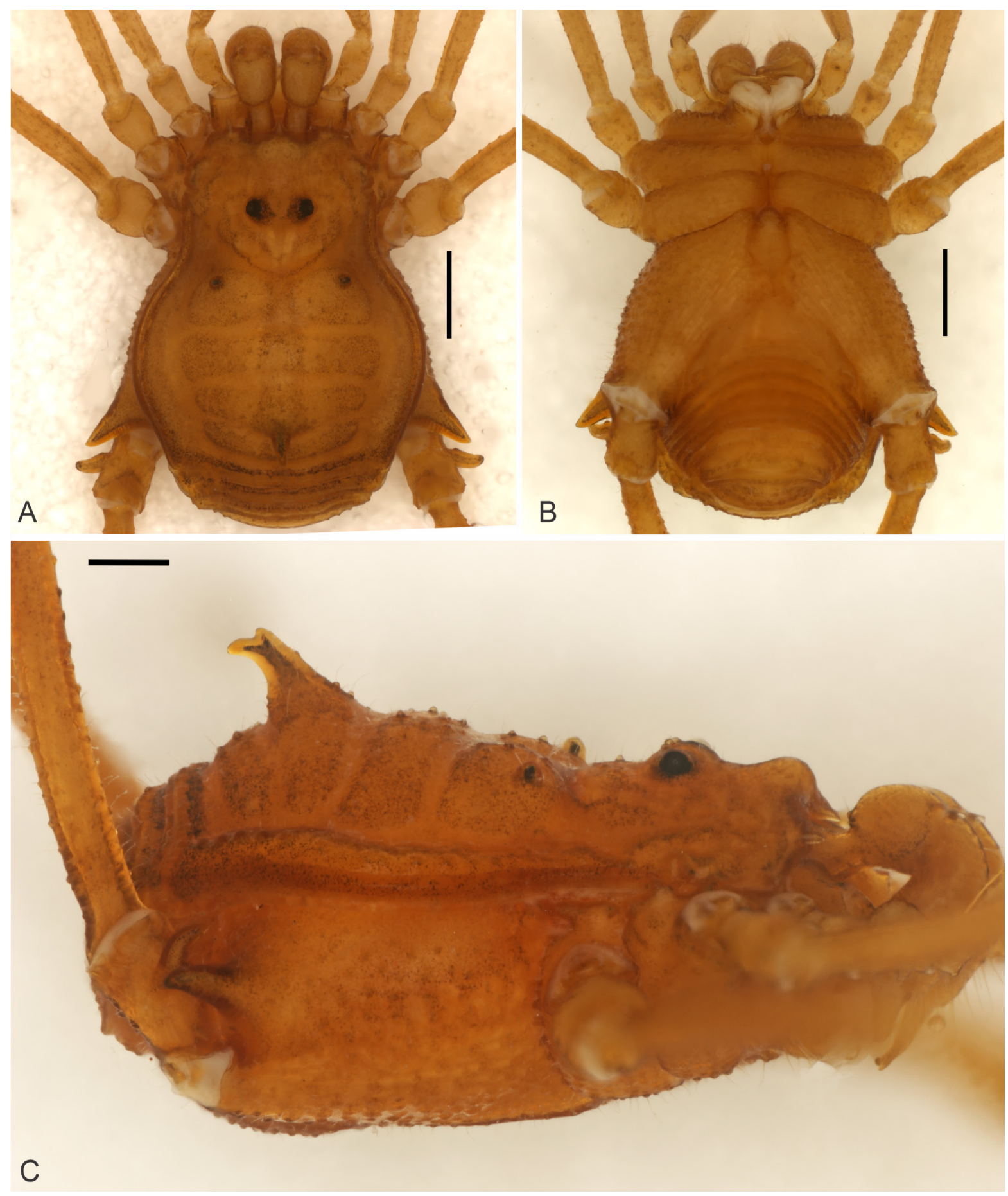

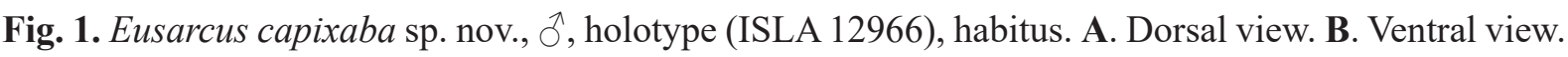
C. Right lateral view. Scale bars: $\mathrm{A}-\mathrm{B}=1 \mathrm{~mm} ; \mathrm{C}=0.5 \mathrm{~mm}$. 

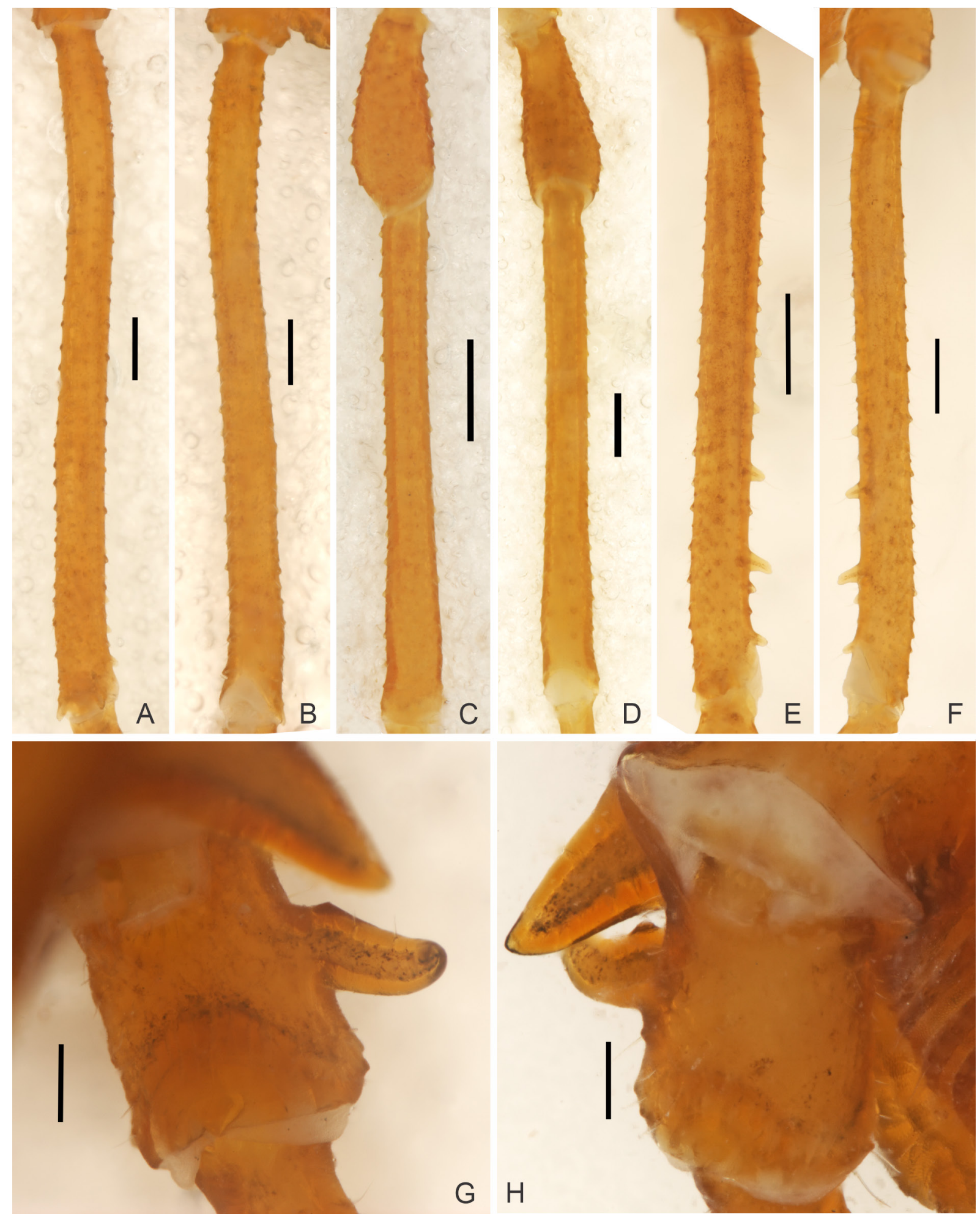

Fig. 2. Eusarcus capixaba sp. nov., đ̂, holotype (ISLA 12966). A-B. Femur IV, dorsal and ventral view, respectively. C-D. Patella and tibia IV, dorsal and ventral view, respectively. E-F. Femur III, dorsal and ventral view, respectively. G-H. Trochanter IV, dorsal and ventral view, respectively. Scale bars: A-F = $0.5 \mathrm{~mm} ; \mathrm{G}-\mathrm{H}=0.2 \mathrm{~mm}$. 

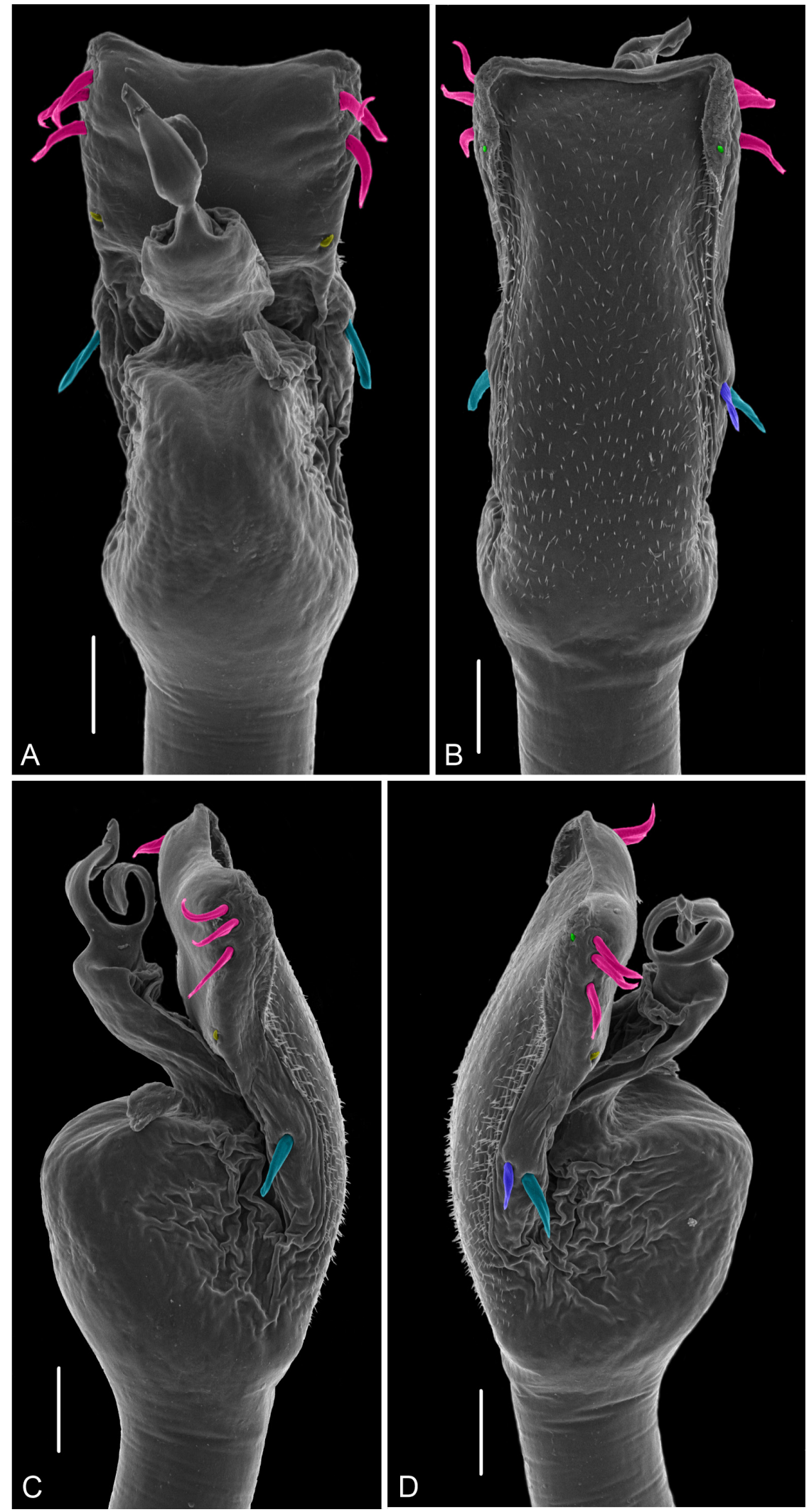

Fig. 3. Eusarcus capixaba sp. nov., Ô, holotype (ISLA 12966), distal part of penis. A. Dorsal view. B. Ventral view. C. Right lateral view. D. Left lateral view. Macrosetae highlighted in different colours: light blue $=$ MS A; purple $=$ MS B; pink $=$ MS C; yellow $=$ MS D; green $=$ MS E. Scale bars $=50 \mu \mathrm{m}$. 
VENTER (FIG. 1B). Coxa I with irregular row of setiferous tubercles, coxae II-IV densely and irregularly granulated.

Chelicerae. Segment I with three basal and one apical tubercle.

PeDIPALPS. Trochanter inflated with sparse tubercles dorsally. Femur with one mesal apical setiferous tubercle.

LEGS (Fig. 2). Coxae I-IV with scattered granules; coxa IV with one oblique proapical apophysis, which is conical, short and curved posteriorly. Trochanters I-IV with scattered tubercles; trochanter IV with one promedian apophysis, which is conical, slightly curved dorsally and with a sub-basal granule. Femur III with retroventral row of about three main pointed tubercles on apical portion; femur IV slightly sinuous, with small PDS and RDS, with proventral and retroventral rows of tubercles similar to granules. Patellae, tibiae and metatarsi I-IV granulated without defined armature.

Colouration (in alcohol) (Figs 1-2). Background colour of body and appendages Deep Orange (51), pair of tubercles on scutal area I with black inner pigmentation, segments Brilliant Orange (49).

PenIs (Fig. 3). Ventral plate with substraight lateral margins; distal margin slightly concave; ventral surface entirely covered with type T1 microsetae; with 3 pairs of lateral-distal MS C1-C3, one pair of A1 and B1 and one pair of minute D1 and E1. Stylus smooth, ventrally tilted, with basis flattened, median region swollen and with an internal depression forming a distinct groove. Ventral process spatula-shaped, dorsally and basally tilted.

\section{Female}

Unknown.

\section{Intraspecific variation}

Males (n = 2): DSL 4.32-4.80; DSW 3.28-3.46; femur I 2.26-2.72; II 5.69-6.05; III 4.18-3.12; IV 5.245.78. Spine of scutal area III with apex single or bifid.

\section{Geographical distribution}

Known only from the type locality (Fig. 11).

\section{Ecological remarks}

Caverna do Sítio Paraíso is a small granite cave at the base of a massive granitic outcrop located in the municipality of Ecoporanga (Espírito Santo State, southeastern Brazil). The cave corresponds to a straight-line conduit with 12 meters of horizontal projection. This conduit is quite narrow (around 1 meter), although it is quite high. At the time of collection, the cave was inhabited by a small colony of guano producing carnivorous bats [Chrotopterus auritus (Peters, 1856)]. The guano pile, apparently the only detectable organic resource within the cave, was located in the deepest portion of the cave. The specimen of Eusarcus capixaba sp. nov. was found freely walking around the faecal pellets that formed the guano pile. It is important to mention that one of the authors (R.L. Ferreira), who collected the specimen, contracted histoplasmosis (a disease caused by the fungus Histoplasma capsulatum Darling) during the visit to this cave, and so caution should be taken during any future surveys. Since no sampling was conducted outside the cave, it is impossible to determine the habitat preference of this species. The landscape surrounding the cave is partially altered, although a forest occurs around the granitic outcrop. The external vegetation is of the Atlantic Forest domain, and the region presents an Aw5 climate according to the Köppen classification system, with an average annual precipitation of around $1082 \mathrm{~mm}$ and an average annual temperature of $24.7^{\circ} \mathrm{C}$. 


\section{Eusarcus marmoreus sp. nov. urn:lsid:zoobank.org:act:39CE9706-C0D6-49A2-9832-FD777C5201CF}

Figs 4-6, 10-11

\section{Diagnosis}

Eusarcus marmoreus sp. nov. can be distinguished from all species of the genus by having coxa IV with one transversal, proapical, trifurcated and truncated apophysis, with one dorsal apex higher than the other two ventrally-disposed apices. Eusarcus marmoreus sp. nov. resembles E. berlae (Mello-Leitão, 1932), E. sergipanus Hara \& Pinto-da-Rocha, 2010, E. signatus (Roewer, 1949) and E. sooretamae (Soares \& Soares, 1946) by the presence of a proapical truncated apophysis at coxa IV but can be distinguished by the following characters: unarmed scutal area III, low ocularium with a median spine, femur IV with proventral and retroventral rows of acuminate tubercles increasing in size apically and trochanter IV with only one high (taller than trochanter width) promedian apophysis.

\section{Etymology}

The specific epithet 'marmoreus' means 'of marble' in Latin and refers to the lithology of the cave where the type specimen was found.

\section{Material examined}

\section{Holotype}

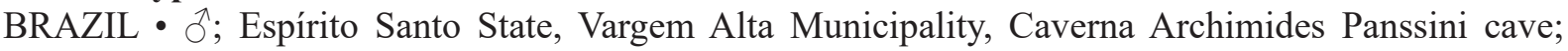
2041'15.3" S, 4103'45.0" W; 4 Apr. 2014; R.L. Ferreira et al. leg.; ISLA 12968 (destroyed).

\section{Paratypes}

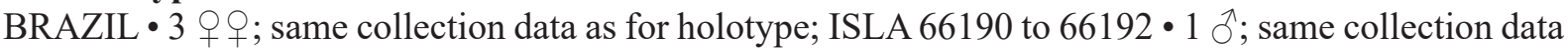
as for holotype; ISLA 1472 (destroyed).

\section{Description}

Male (holotype, ISLA 12968)

MEASUREMENTS. DSL 4.79, DSW 3.41, femur I 2.72, II 6.27, III 4.08, IV 5.03.

Dorsum (Fig. 4A, E). Blunt PAM; acuminate median paracheliceral projection lower than PAM. Low ocularium with median spine (about two times ocularium height). Carapace with scattered granules. Scutal areas I-IV with scattered granules with higher density on scutal areas III-IV. Posterior margin of dorsal scutum with scattered granules. Free tergites I-III with a defined row of granules. Anal operculum with scattered granules.

Venter (Fig. 4B). Coxa I with irregular row of setiferous tubercles, coxae II-IV densely and irregularly granulate.

Chelicerae. Segment I with two ectal-basal tubercles fused at the base and one irregular mesal-basal tubercle.

PEDIPALPS. Trochanter with sparse tubercles dorsally. Femur with one mesal apical setiferous tubercle.

LEGS (Fig. 5). Coxae I-III with scattered granules; coxa IV with one transversal, proapical, trifurcated and truncated apophysis, with one dorsal apex higher than the other two ventrally-disposed apices. Trochanters I-IV with scattered tubercles; trochanter IV with one high (taller than trochanter width) promedian apophysis, which is conical, with rounded and anteriorly-curved apex. Femur III with proventral and retroventral rows of acute tubercles increasing in size apically; femur IV slightly sinuous, with small PDS and RDS, with proventral and retroventral rows of acuminate tubercles increasing in size apically. Patellae, tibiae and metatarsi I-IV granulated without defined armature. 


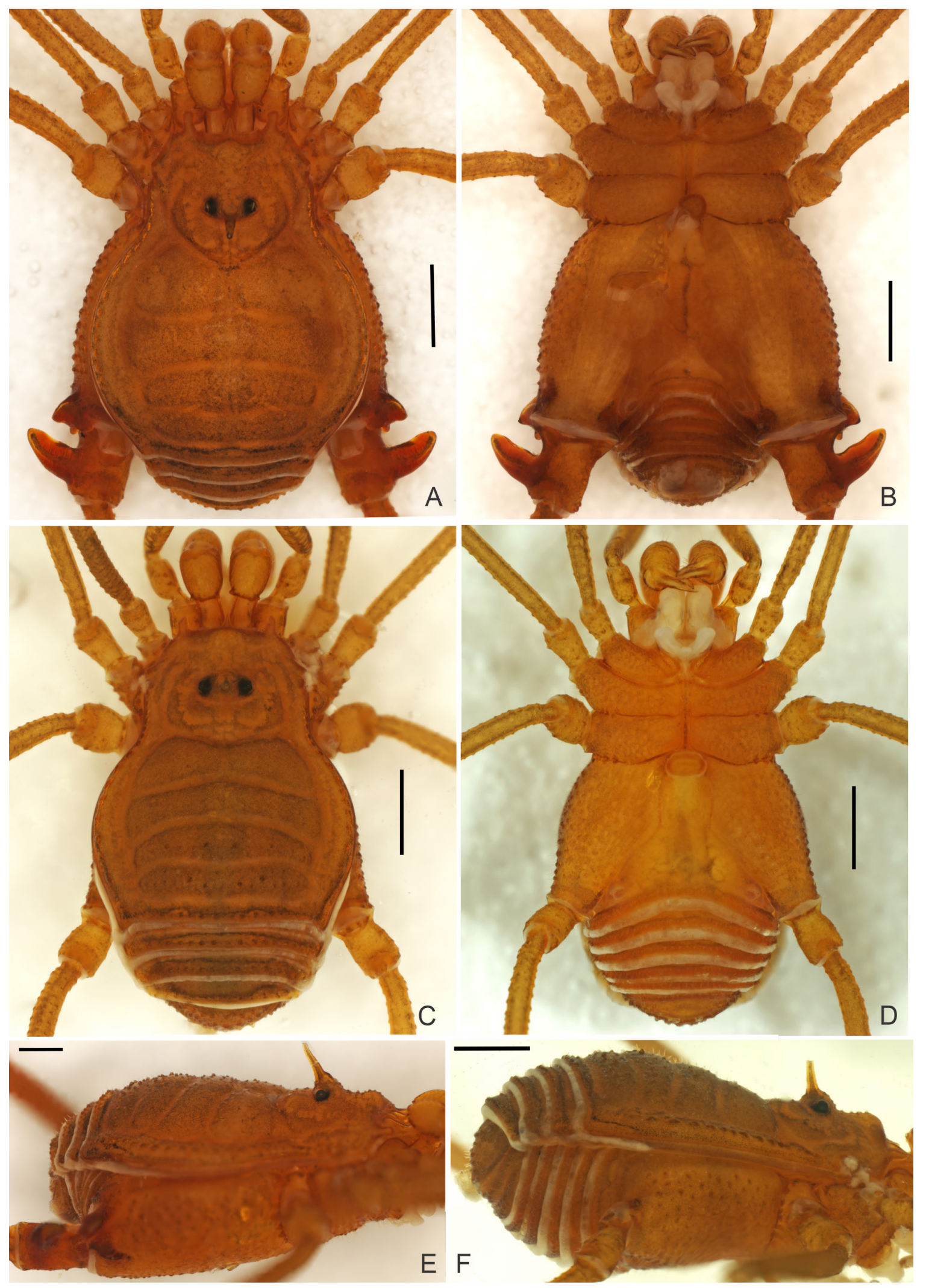

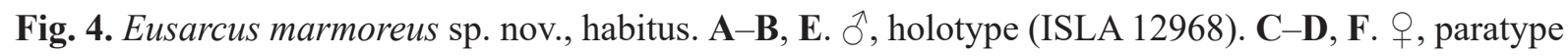
(ISLA 66190). A. Dorsal view. B. Ventral view. C. Dorsal view. D. Ventral view. E-F. Right lateral view. Scale bars: $\mathrm{A}-\mathrm{E}=1 \mathrm{~mm} ; \mathrm{F}=0.5 \mathrm{~mm}$. 


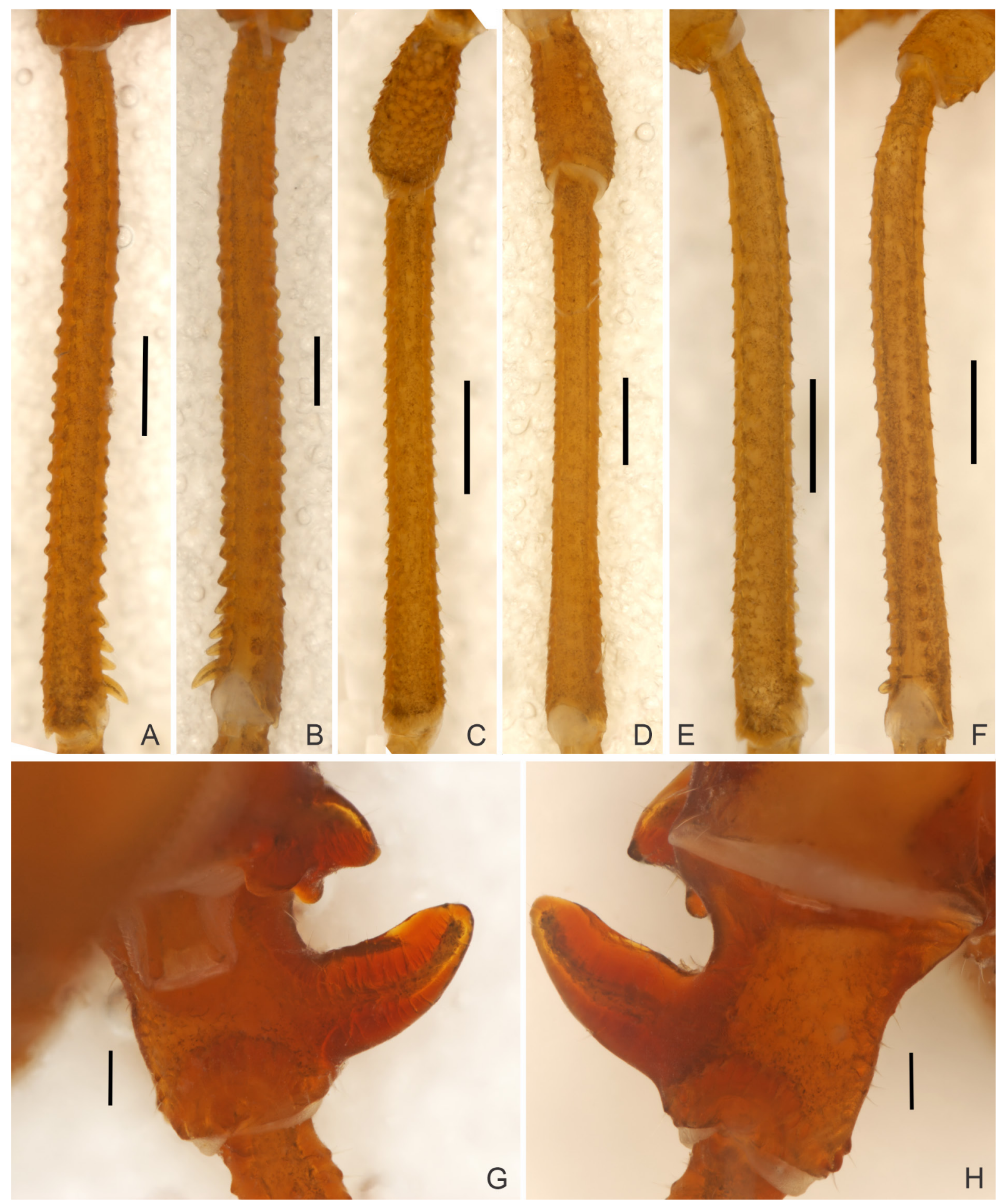

Fig. 5. Eusarcus marmoreus sp. nov., Ô, holotype (ISLA 12968). A-B. Femur IV, dorsal and ventral view, respectively. C-D. Patella and tibia IV, dorsal and ventral view, respectively. E-F. Femur III, dorsal and ventral view, respectively. G-H. Trochanter IV dorsal and ventral view, respectively. Scale bars: $\mathrm{A}-\mathrm{F}=0.5 \mathrm{~mm} ; \mathrm{G}-\mathrm{H}=0.2 \mathrm{~mm}$. 

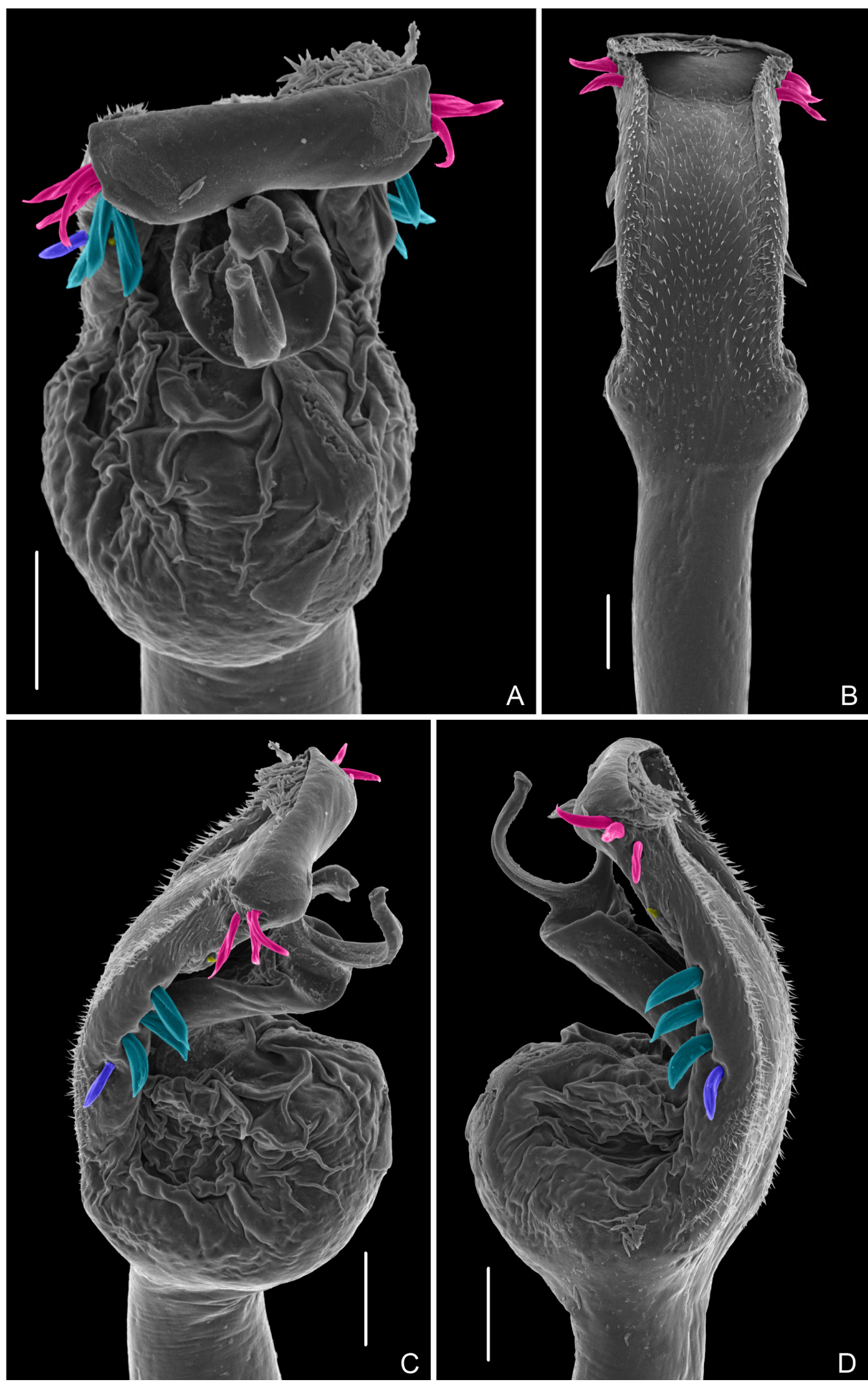

Fig. 6. Eusarcus marmoreus sp. nov., Ô, holotype (ISLA 12968), distal part of penis. A. Dorsal view. B. Ventral view. C. Right lateral view. D. Left lateral view. Macrosetae highlighted in different colours: light blue $=$ MS A; purple $=$ MS B; pink $=$ MS C; yellow $=$ MS D. Scale bars $50 \mu \mathrm{m}$. 
Colouration (in alcohol) (Figs 4-5). Body and appendages background colour Strong Brown (55), appendages Strong Orange (50).

Penis (Fig. 6). Ventral plate dorsally concave with substraight lateral margins; distal margin straight; ventral surface entirely covered with type $\mathrm{T} 1$ microsetae; with three pairs of lateral-distal MS C1-C3, three wide pairs of A1, one pair of B1, one pair of minute D1, and E1 absent. Stylus smooth, wider at apex, ventrally tilted. Ventral process spatula-shaped, dorsally tilted.

Female (paratype, ISLA 66190)

MEASUREMENTS. DSL 4.73, DSW 2.93, femur I 2.40, II 5.18, III 3.57, IV 4.53.

Similar to male, except for leg IV unarmed with only coxa IV having one short proapical tubercle.

\section{Intraspecific variation}

Males $(\mathrm{n}=2)$ : DSL 4.79-4.17; DSW 3.41-3.02, femur I 2.72-2.44, II 6.27-6.11, III 4.08-4.20, IV 5.035.12 .

\section{Geographical distribution}

Known only from the type locality (Fig. 11).

\section{Ecological remarks}

Archimides Panssini is a marble cave located in Vargem Alta Municipality (Espírito Santo State, southreastern Brazil). It possesses around 150 meters of horizontal projection, with an irregular topography. The inner cave chamber harbours a small amount of water flow. Thus, organic resources observed in the cave were vegetal debris brought in by water flow and piles of bat guano, especially those produced by hematophagous bats. Roots from the external vegetation were also observed in a few areas. Specimens of Eusarcus marmoreus sp. nov. were found freely walking in the inner cave chambers, usually associated with moistened substrates (Fig. 10B). The Archimides Panssini Cave is also the type locality of the troglobitic palpigrade Eukoenenia spelunca Souza \& Ferreira, 2011 (Souza \& Ferreira 2011), which reinforces its relevance. The cave is located in the Atlantic Forest domain, and the external landscape is topographically heterogeneous. The region presents a Cwa climate according to the Köppen classification system, with an average annual precipitation ranging from 1000 to $1300 \mathrm{~mm}$ and an average annual temperature of $20.9^{\circ} \mathrm{C}$. The external landscape is quite altered, especially due to the removal of native vegetation for crops. Furthermore, many quarries for the extraction of marble were observed in the area during the last visit (in 2014) (Fig. 10A), which represents a serious threat for species associated with caves.

Eusarcus xambioa sp. nov. urn:1sid:zoobank.org:act:96736EDB-2D6D-48A0-9FA8-9D41BCBAEA9F

Figs 7-11

\section{Diagnosis}

Eusarcus xambioa sp. nov. resembles E. aduncus, E. armatus, E. cavernicola, E. dandara, E. fulvus, E. mirabilis and E. oxyacanthus by having coxa IV with one transversal, proapical, acute and conical apophysis but can be distinguished by the following characters: short (shorter than trochanter IV width) probasal apophysis on trochanter IV, high ocularium with spine, and femur IV with proventral and retroventral rows of acuminate tubercles increasing in size apically. 


\section{Etymology}

The specific epithet 'xambioa' means 'fast bird' in the Tupi language and refers to a group of natives of the Araguaia River. It also refers to the municipality where the type was found.

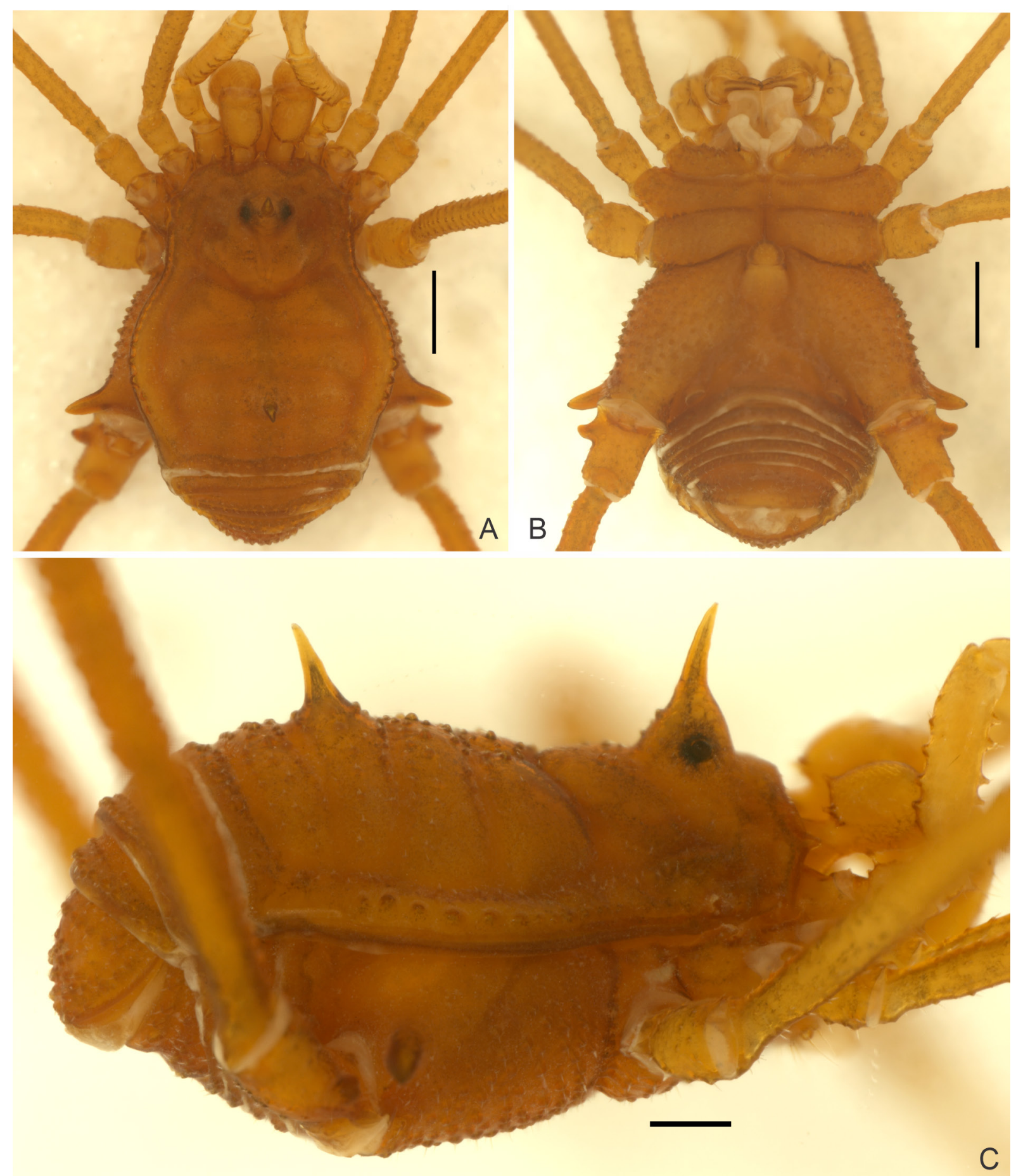

Fig. 7. Eusarcus xambioa sp. nov., $\widehat{0}$, holotype (ISLA 60386), habitus. A. Dorsal view. B. Ventral view. C. Lateral view. Scale bars: $\mathrm{A}-\mathrm{B}=1 \mathrm{~mm} ; \mathrm{C}=0.5 \mathrm{~mm}$. 

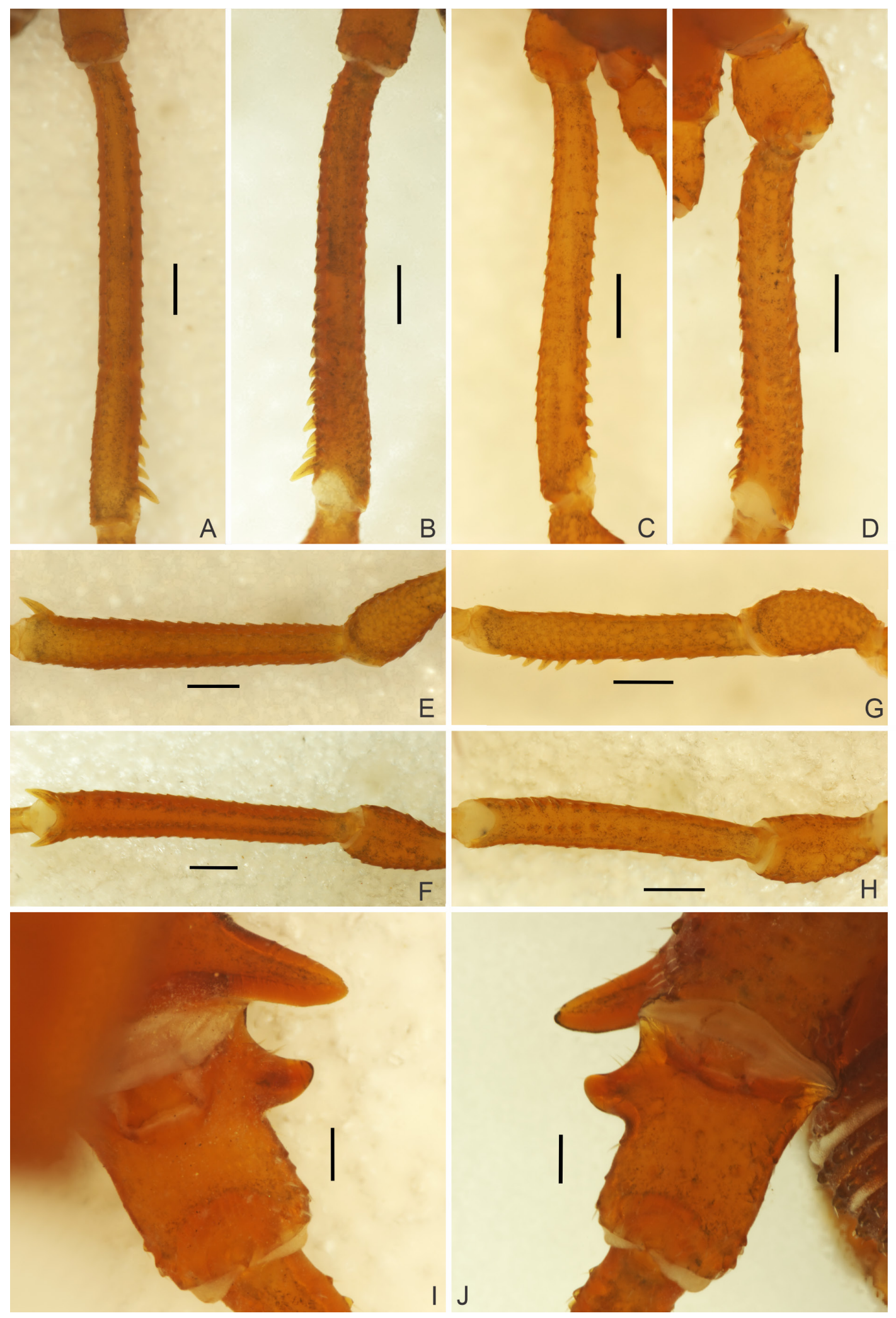

Fig. 8. Eusarcus xambioa sp. nov., ${ }^{\Uparrow}$, holotype (ISLA 60386). A-B. Femur IV, dorsal and ventral view, respectively. C-D. Femur III, dorsal and ventral view, respectively. E-F. Patella and tibia IV, dorsal and ventral view, respectively. G-H. Patella and tibia III, dorsal and ventral view, respectively. I- J. Detail of trochanter IV, dorsal and ventral view, respectively. Scale bars: A-H $=0.5 \mathrm{~mm}$; $\mathrm{I}-\mathrm{J}=0.2 \mathrm{~mm}$. 


\section{Material examined}

\section{Holotype}

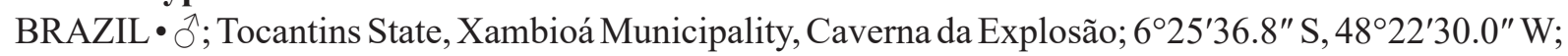

21 Feb. 2018; R.L. Ferreira et al. leg; ISLA 60386.

\section{Description}

Male (holotype, ISLA 60386)

MEASUREMENTS. DSL 3.77, DSW 3.19, femur I 2.38, II 4.80, III 3.25, IV 4.49.

Dorsum (Fig. 7A, C). Blunt PAM; acuminate median paracheliceral projection similar in size to PAM. High ocularium with median spine (about twice times ocularium height). Carapace with scattered granules. Scutal areas I-IV with scattered granules with some tubercles among them. Posterior margin of dorsal scutum with scattered granules. Lateral margins with blunt tubercles about the same size as those on the scutum. Free tergites I-III with a defined row of granules. Anal operculum with scattered granules.

VENTER (Fig. 7B). Coxa I with irregular row of setiferous tubercles, coxae II-IV densely and irregularly granulate.

Chelicerae. Segment I with two ectal-basal tubercles and one mesal-basal tubercle.

PEDIPALPS. Trochanter with sparse tubercles dorsally. Femur with one mesal apical setiferous tubercle. Tibia setation: ectal IiIi, mesal IiIi; tarsus setation: ectal IIIi, mesal IIi.

LEGS (Fig. 8). Coxae I-III with scattered granules; coxa IV with one transversal, prolateral and apical apophysis, which is conical and short. Trochanters I-IV with scattered tubercles; trochanter IV with one probasal apophysis, which is conical, short and dorsally oriented. Femur III with proventral and retroventral rows of acute tubercles increasing in size apically; tibia III with proventral and retroventral
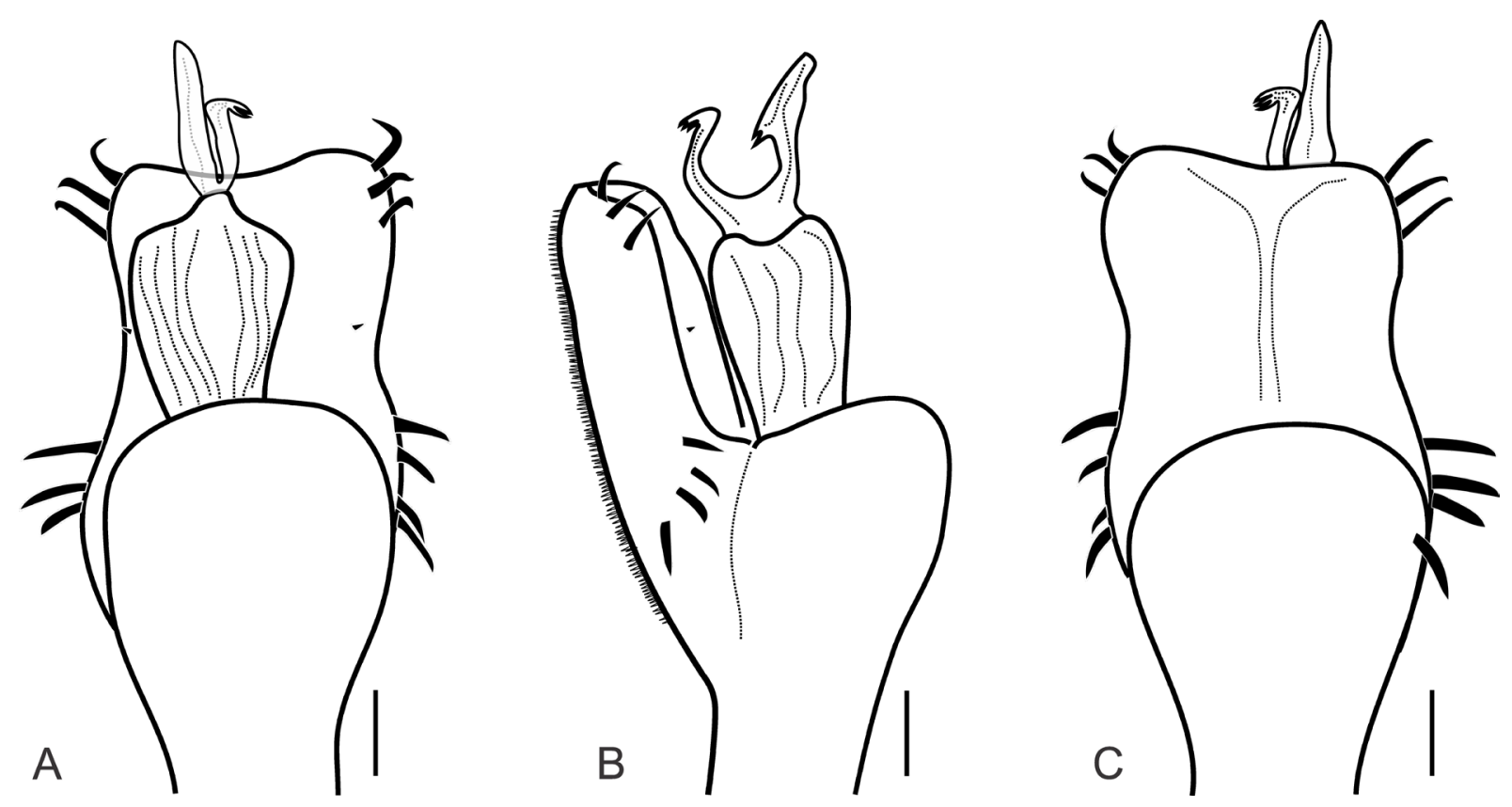

Fig. 9. Eusarcus xambioa sp. nov., $\widehat{\jmath}$, holotype (ISLA 60386), distal part of penis. A. Dorsal view. B. Ventral view. C. Right lateral view. Scale bars $=50 \mu \mathrm{m}$. 
rows of acuminate tubercles. Femur IV slightly sinuous, with small PDS and RDS, proventral row of acuminate tubercles increasing in size apically and retroventral row with reduced tubercles; tibia IV with proventral and retroventral rows of acuminate tubercles increasing in size subapically.

PENIS (Fig. 9). Ventral plate with substraight lateral margins; distal margin slightly concave; ventral surface entirely covered with type T1 microsetae; with three pairs of lateral-distal MS C1-C3, three pairs of A1, one pair of B1, one pair of minute D1 and E1 absent. Stylus with ventrally-tilted medianventral trichomes. Ventral process tubular, curved, with apex with flabelliform projection.

Colouration (in alcohol) (Figs 7-8). Body and appendages background colour Deep Orange Yellow (69), appendages Strong Orange Yellow (68).

\section{Female}

\section{Unknown.}

\section{Geographical distribution}

Known only from the type locality (Fig. 11).
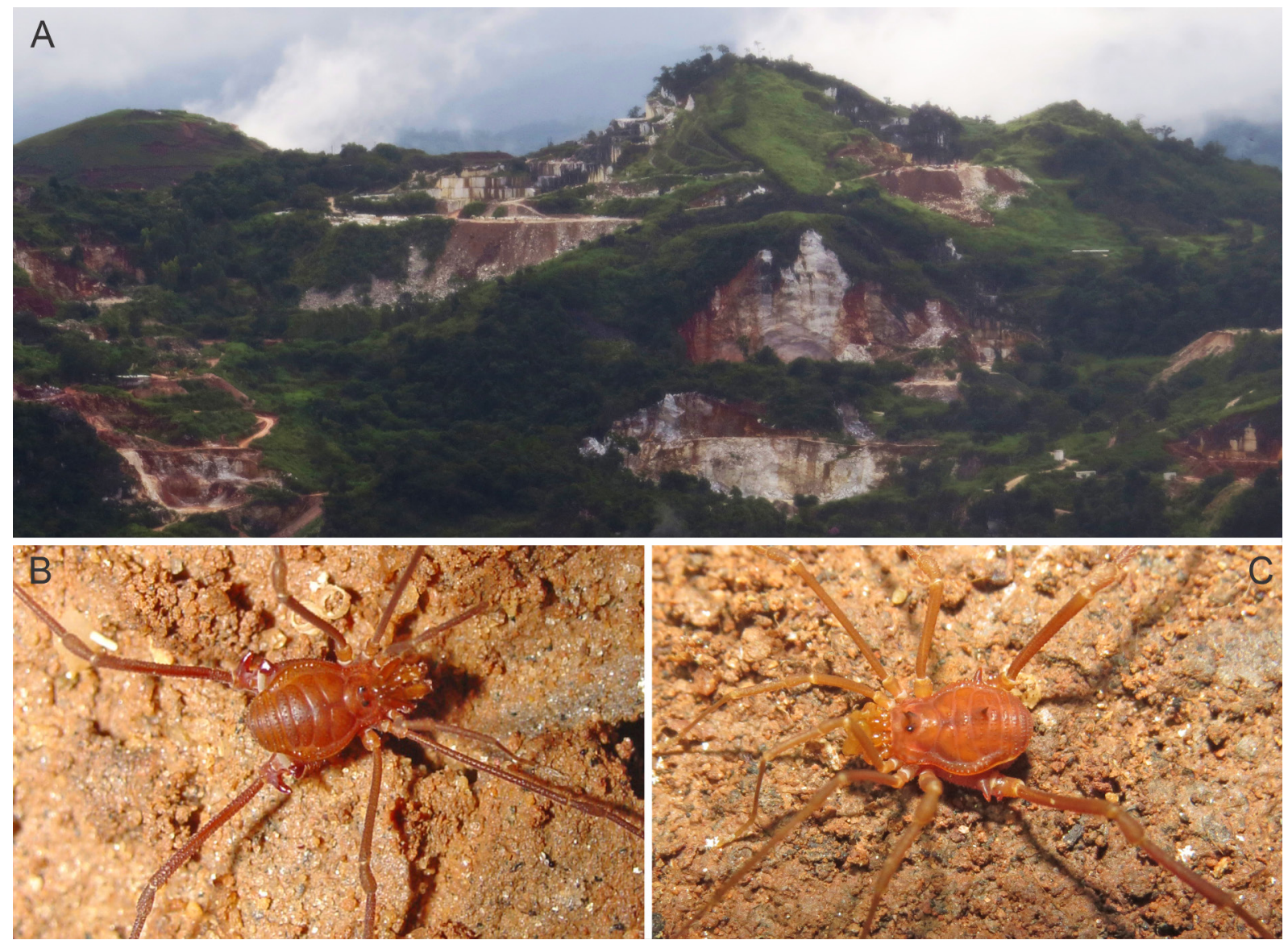

Fig. 10. A. External landscape of Vargem Alta Municipality, with many quarries for marble extraction. B. Living specimen of Eusarcus marmoreus sp. nov., Ô, holotype (ISLA 12968) from Caverna Archimides Panssini Cave, Vargem Alta Municipality, Espírito Santo State, Brazil. C. Living specimen of Eusarcus xambioa sp. nov., Ō, holotype (ISLA 60386) from Caverna da Explosão Cave, Xambioá Municipality, Tocantins State, Brazil. Photos by R.L. Ferreira. 


\section{Ecological remarks}

Caverna da Explosão is a limestone cave with 1203 meters of horizontal projection. The main entrance of the cave collapsed in the past, so that the access to the cave interior is currently made through a small entrance located at the base of the outcrop, leading to a very narrow passage. Most of the cave floor is covered with terrigenous sediments, although a few fallen blocks are also present. Most of the organic resources occurring in the cave are vegetal debris transported by water during strong rains and especially bat guano, produced by a variety of bat species, although droppings of hematophagous bats are the most common ones. Despite the lack of any regular water flow, several areas of the cave can be partially submerged during the rainy period. The single collected specimen was observed freely walking on the cave floor (Fig. 10C), close to a guano pile produced by hematophagous bats. Since the cave was not completely surveyed during our sampling, there is no indication of the size of the species' population and its density inside the cave. The region presents an Aw5 climate according to the Köppen classification system, with an average annual precipitation of around $1558 \mathrm{~mm}$ and an average

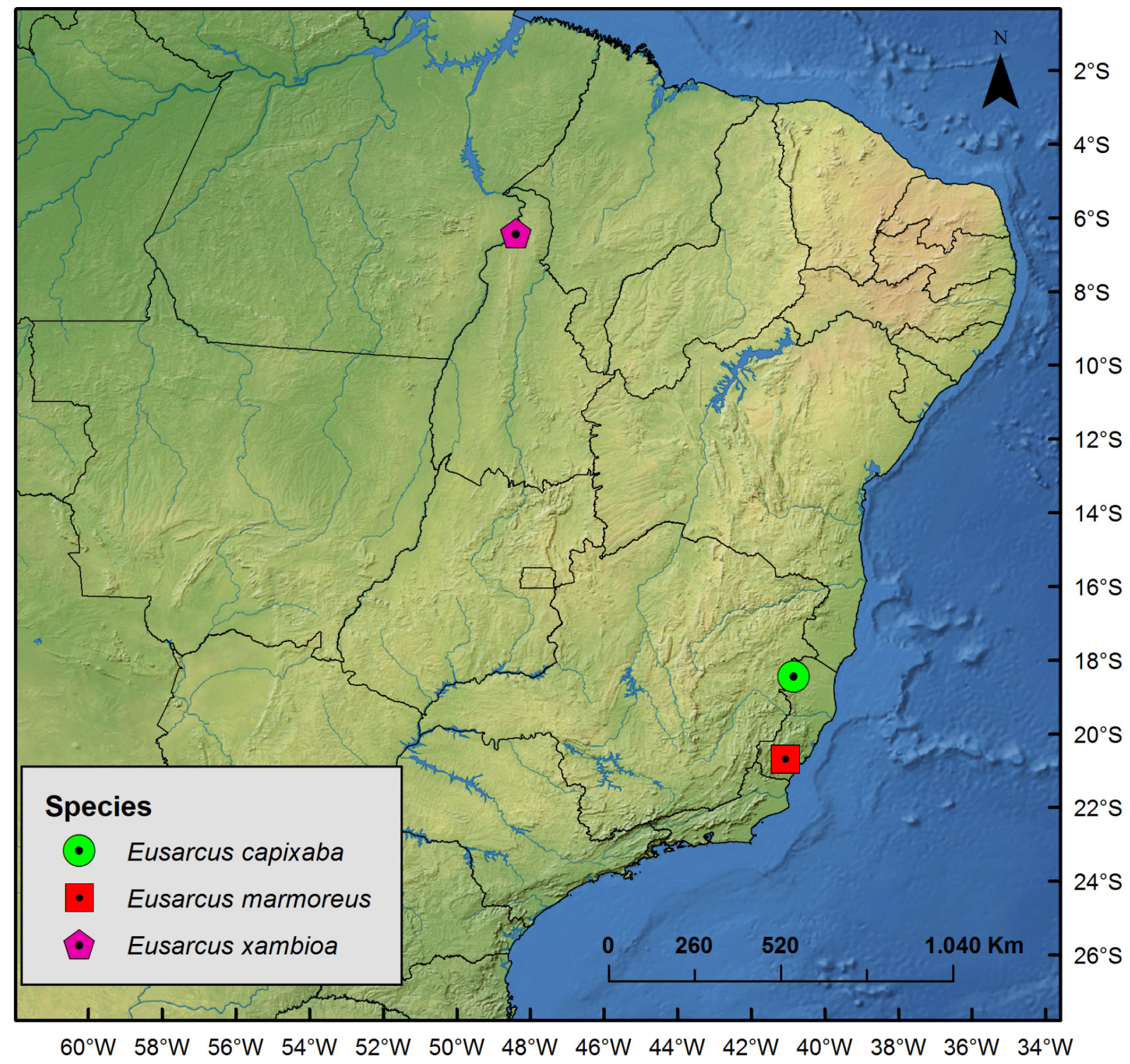

Fig. 11. Known distribution of Eusarcus capixaba sp. nov., Eusarcus marmoreus sp. nov. and Eusarcus xambioa sp. nov. in Brazil. 
annual temperature of $26.3^{\circ} \mathrm{C}$. The external area is quite altered, especially due the replacement of natural vegetation by Eucalyptus L'Hér. plantations. However, the outcrop where the cave is located is surrounded by secondary forest. As with the other species described herein, the area outside the cave was not sampled, so it is impossible to determine the habitat preference for this species.

\section{Discussion}

Among the 61 genera of Gonyleptoidea associated with Brazilian caves (Ázara \& Ferreira 2018), Eusarcus turns out to be the most diverse with 14 species found in and around subterranean environments. Although the three new species described here were recorded only for caves, none of them exhibits any troglomorphic traits (e.g., depigmentation, elongated appendages); thus, they are not troglobites in the strict sense.

Eusarcus xambioa sp. nov. is the second species of the genus described from Tocantins State, a region with a poorly known opilionofauna, which is true for many regions of northeastern Brazil (Kury 2003; Kury et al. 2010; Ázara \& Ferreira 2018). This species, together with E. sulcatus (Piza, 1940) (from Tocantins State), E. sergipanus Hara \& Pinto-da-Rocha, 2010 (from Sergipe State) and E. dandara Saraiva \& DaSilva, 2016 (from Alagoas State), are the northernmost records for the genus (Saraiva \& DaSilva 2016).

Eusarcus capixaba sp. nov. is unique within the genus due to the presence of a pair of high, blunt and black tubercles in scutal area I. The only other species that possesses armature on area I is Eusarcus teresincola Soares \& Soares, 1946. However, E. teresincola possesses acuminate tubercles and, besides that, the dorsal scutum is clearly marked with a dark brown reticulated pattern, a unique feature in the genus.

Considering that all three of the species described herein are not cave-restricted, the impacts observed in most of the external landscapes where the caves are located certainly represent a concern. It is likely that the main habitat of some of these species is forest, and the caves represent eventually only peripheral habitats. Thus, it is important that not only the caves are preserved, but also the natural forests surrounding them. Furthermore, it is advisable that future surveys are conducted in the surroundings of these caves in order to determine the true range of the species' habitats.

\section{Acknowledgements}

The SEM micrographs were taken in the SEM Lab of Marine Diversity of the MNRJ (financed by PETROBRAS), with the kind assistance of Camila Messias and Beatriz Cordeiro. LNA was supported by a scholarship from Fundação de Amparo à Pesquisa do Estado do Rio de Janeiro (FAPERJ) (\#E26/200.605/2018). RLF is thankful to CNPq (National Council of Technological and Scientific Development) for funding support (grant No. 308334/2018-3). Finally, we thank Marconi Souza Silva for the support with field sampling (financed by the Critical Ecossystem Partnership Fund - CEPF).

\section{References}

Ázara L.N. \& Ferreira R.L. 2018. Annotated checklist of Gonyleptoidea (Opiliones: Laniatores) associated with Brazilian caves. Zootaxa 4439 (1): 1-107. https://doi.org/10.11646/zootaxa.4439.1.1

Hara M.R. \& Pinto-da-Rocha R. 2010. Systematic review and cladistic analysis of the genus Eusarcus Perty 1833 (Arachnida, Opiliones, Gonyleptidae). Zootaxa 2698: 1-136.

https://doi.org/10.11646/zootaxa.2698.1.1

DaSilva M.B. \& Gnaspini P. 2010. A systematic revision of Goniosomatinae (Arachnida: Opiliones: Gonyleptidae), with a cladistic analysis and biogeographical notes. Invertebrate Systematics 23: 530624. https://doi.org/10.1071/IS09022 
Krell F.-T. \& Marshall S.A. 2017. New species described from photographs: Yes? No? Sometimes? A fierce debate and a new declaration of the ICZN. Insect Systematics and Diversity 1: 3-19. https://doi.org/10.1093/isd/ixx004

Kury A.B. 2003. Annotated catalogue of the Laniatores of the New World (Arachnida, Opiliones). Revista Iberica de Aracnología 1: 1-337.

Kury A.B. 2016. A classification of the penial microsetae of Gonyleptoidea (Opiliones: Laniatores). Zootaxa 4179 (1): 144-150. https://doi.org/10.11646/zootaxa.4179.1.13

Kury A.B. \& Medrano M. 2016. Review of terminology for the outline of dorsal scutum in Laniatores (Arachnida, Opiliones). Zootaxa 4097 (1): 130-134. https://doi.org/10.11646/zootaxa.4097.1.9

Kury A.B. \& Orrico V.G.D. 2006. A new species of Lacronia Strand, 1942 from the highlands of Rio de Janeiro (Opiliones, Gonyleptidae, Pachylinae). Revista Ibérica de Aracnologia 13: 147-153.

Kury A.B. \& Villarreal O.M. 2015. The prickly blade mapped: establishing homologies and a chaetotaxy for macrosetae of penis ventral plate in Gonyleptoidea (Arachnida, Opiliones, Laniatores). Zoological Journal of the Linnean Society (174) 1: 1-46. https://doi.org/10.1111/zoj.12225

Kury A.B., Chagas-Jr A., Giupponi A.P.L. \& Pérez Gonzáles A. 2010. Amblypygi, Opiliones, Schizomida, Scorpiones and Chilopoda, Tocantins, Brazil. Check List 6 (4): 564-571. https://doi.org/10.15560/6.4.564

Kury A.B., Giupponi A.P.L. \& Mendes A.C. 2018. Immolation of Museu Nacional, Rio de Janeiro unforgettable fire and irreplaceable loss. Journal of Arachnology 46 (3): 556-558.

https://doi.org/10.1636/JoA-S-18-094.1

Mello-Leitão C.F. de. 1942. Oito novos opiliões do Espírito Santo. Boletim do Museu Nacional 14 (17): $1-11$.

Piza S.T. de Jr 1940. Novos Gonyleptidae do Brasil. Arquivos de Zoologia do Estado de São Paulo 1 (2): $53-66$.

Saraiva. N.E.V. \& DaSilva M.B. 2016. Event-based biogeography of Eusarcus dandara sp. nov. (Opiliones: Gonyleptidae), an endemic species of the Northern Atlantic Rainfores of Brazil, and its closely related species. Zootaxa 4205 (6): 532-548. https://doi.org/10.11646/zootaxa.4205.6.2

Souza M.F.V.R. \& Ferreira R.L. 2011. A new troglobitic Eukoenenia (Palpigradi: Eukoeneniidae) from Brazil. The Journal of Arachnology 39: 185-188. https://doi.org/10.1636/Ha10-43.1

Manuscript received: 3 July 2020

Manuscript accepted: 17 January 2021

Published on: 23 March 2021

Topic editor: Rudy C.A.M. Jocqué

Desk editor: Radka Rosenbaumová

Printed versions of all papers are also deposited in the libraries of the institutes that are members of the EJT consortium: Muséum national d'histoire naturelle, Paris, France; Meise Botanic Garden, Belgium; Royal Museum for Central Africa, Tervuren, Belgium; Royal Belgian Institute of Natural Sciences, Brussels, Belgium; Natural History Museum of Denmark, Copenhagen, Denmark; Naturalis Biodiversity Center, Leiden, the Netherlands; Museo Nacional de Ciencias Naturales-CSIC, Madrid, Spain; Real Jardín Botánico de Madrid CSIC, Spain; Zoological Research Museum Alexander Koenig, Bonn, Germany; National Museum, Prague, Czech Republic. 